\title{
University Instructors' Teaching Experience and Their Perception of Professional Ethics: Postulating a Model
}

\section{Zeinab Kafi}

Department of English, Torbat-e Heydarieh Branch, Islamic Azad University, Torbat-e Heydarieh, Iran, kafizb@gmail.com

\section{Khalil Motallebzadeh}

Assoc. Prof., corresponding author, Department of English, Torbat-e Heydarieh Branch, Islamic Azad University, Torbat-e Heydarieh, Iran, kmotallebz@gmail.com

\section{Hamid Ashraf}

Asst. Prof., Department of English, Torbat-e Heydarieh Branch, Islamic Azad University, Torbat-e Heydarieh, Iran, hamid.ashraf.elt@ gmail.com

As Campbell (2008) skillfully explains, "the field of ethics in teaching as a moral profession is a robust and compelling one. It captures the interest and imagination of scholars, researchers, and practitioners alike because it is very important and integral to the world of education" (p.21). Similarly, in many EFL countries including Iran, professional ethics has recently turned into a crucial topic. Consequently, further researches regarding the notion of ethics, its components and whether experience plays a role in this regard, need to be carried out. Throughout the current article, the researchers, at first place, illustrated the importance of professional ethics in teaching through a thorough review of literature. Afterwards, a previously localized code of professional ethics, which was transformed into a validated instrument for data collection, was deployed to gather data from $200 \mathrm{EFL}$ male and female university instructors. Pearson Correlation was administered to investigate the probable relation between EFL university instructors' teaching experience and their understanding of professional ethics. Also, to prioritize the components of professional ethics based on EFL instructors' perspective, Friedman test was deployed and the results are disused according to EFL teaching learning context.

Keywords: ethics, professional ethics, model of code of professional ethics, ethical behaviour, professionalism, university instructors

Citation: Kafi, Z., Motallebzadeh, K., \& Ashraf, H. (2018). University Instructors' Teaching Experience and Their Perception of Professional Ethics: Postulating a Model. International Journal of Instruction, 11(4), 257-270. https://doi.org/10.12973/iji.2018.11417a 


\section{INTRODUCTION}

How far we teachers reflect on our ethical behavior when performing our varied teaching responsibilities? Are teachers familiar with the varied aspects of professional ethics to which they are expected to be committed? Giving reference to these issues along with many other ethical dilemmas in teaching, it seems logical to shed light on some of the aspects of professional ethics regarding the realm of teaching. Accordingly, it may sound wise, cautious and aware enough to quote the critical questions and thought-provoking ideas of Freeman (2000) to ponder upon the notion of ethics prior to any other aspect of the current study: "What does a good teacher do when faced with kinds of ethical dilemmas? Where do teachers turn when the personal character and morality developed in their youth prove inadequate in the workplace? As teachers claim increased levels of professionalism, they would do well to rely on their professional codes of ethical conduct, for, like others who call themselves professionals, they need these indispensable guideposts when they face difficult situations in the pluralistic and secular world of work. Offering tomorrow's teachers, instruction in professional ethics is critical if we are to prepare them to face the increasingly intense scrutiny that comes with accountability, autonomy, and professional recognition" (Freeman, 2000, p. 2).

Additionally, when it comes to the vitality of ethics in education, one can give reference to quality teaching as one of the stepping stones of professionalism, which has been raised by many language practitioners and it is obvious and generally accepted that "quality education is dependent on teachers - the single most important school-based factor in students education success" (Santoro, 2012, p.2) and needless to say that an ethics code would do a great deal of this quality teaching.

As typically understood, teaching reflects the intentional effort to influence another human being for the good rather than for the bad" (Hansen, 2001b, p. 828, as cited in Campbell, 2008, p. 7). Consequently, many researchers including Campbell (2000) emphasize the importance of providing codes in the way that they "can provide important and useful guidelines regarding ideals, behaviors and decisions" (Beck \& Murphy, 1994, p. 9). Elsewhere in the article, she gives reference to Haynes (1998) saying that codes do provide guidelines to the implementation of ethical values. And she also calls on the idea presented by Lovat (1998) that the endorsement of an ethical code would signal a new maturity for the profession. An overall perspective which is repeatedly observable in her paper is that "teachers ought to seriously engage in teaching as an ethical practice" (Hostetler, 1997, p. 205). In her following article in 2008, Campbell asserts that since teaching is a moral activity, it calls for attention to teachers' conduct, character, perceptions, judgment, and understanding (Hanson, 2001).

Following the same pattern of thought, Freeman (2000, p. 2) provides further proof for the vital existence of an ethics code through applying Kipnis (1986) words on adherence to a code of ethics which is, in fact, one of the important characteristics that differentiates professions from other occupations. He asserts that professionals who know how to "do ethics" think systematically when they face difficult moral decisions. (Nash, 1996; Strike \& Ternasky, 1993). 
Considering all the already discussed issues which are also among the ethical concerns of the EFL academic context of Iran, the core objective of the current study goes back to the fact that still we are observing teachers whose end product of their classes are not fully satisfying, despite the great number of classes they have taught and the huge amount of experience they are tagged with and the enormous number of workshops they have so far picked! Part of this failure, it seems, goes to either the academic contexts' not having a clear-cut set of ethical codes/guidelines for teachers, or teachers' lack of attendance and attention to such provided set of guidelines. Therefore, to investigate the probable relation between EFL teachers' perception of ethics and their years of teaching experience would be an essential step to be taken in the Iranian EFL academic context. Additionally, locating the probable areas/aspects of professional ethics that EFL university instructors declare to have the most and the least amount of awareness about, would be useful for future educational measurer which are necessary to be taken in order to design awareness-raising programs in this regard.

\section{LITERATURE REVIEW}

\section{The Essence of Professionalism}

In their paper, toward an ethics of professional understanding, Tanchuk, Scramstad \& Kruse (2016) argue that "all moral agents, and thus professionals, share a fundamental and constitutive normative interest in correctly conceiving of their end (p. 2)". This means all professionals have got special role responsibilities and in order to maintain these responsibilities they need to have a good conception of their ends. Therefore, the need for professionalism ought to be reflected in any curriculum and this means teachers are advised to have a good understanding of who, what and how they teach and accordingly, under similar situations such a curriculum would make a significant difference in our sense of professional advocacy (Tanchuk et al., 2016). Moving further and beyond the curriculum, we might also locate other aspects which are crucial to one's professionalism and clearly will lead one to be called a professional. One of these intricate aspects that professionalism calls for is ethics and moral aspects of humans (teachers and learners in this regard). Following the same pattern of thought, in his article, Campbell (2008) claims that "the processes of teaching as an interpersonal journey are far more nuanced and layered than what the teacher's mastery of curricula and pedagogical techniques can fully enable. The mysteries of teaching demand attention to the intangibles as well, and such intangibles are morally and ethically infused; they may be perceived in the tone of voice a teacher uses to speak to a child, in the way a teacher justly adjudicates among competing needs and interests in the classroom, in the way a teacher selects resources with care, evaluates student work with honesty and respect, and conducts his or her daily practice with honor, diligence, fairness, and compassion. Taken together, then, ethics and teaching seem inherently compatible and unavoidably intertwined" (p.2). Accordingly, if one cares to be called a good teacher, he needs to care for professionalism and undoubtedly, ethics is one of the stepping stones in professionalism. A proof to this is the claim proposed by Sockett (1992) that "as professionals, teachers strive to understand and uphold the moral imperatives embedded in their work" (as cited in Campbell, 2008, p. 6). 


\section{What an Ethics Code Mean in an Academic Context}

The Australian College of Education Code of Ethics (1987) asserts that while there exists a wide variety and diversity in beliefs among members of a community, "there is present in the community of educators a sufficient measure of agreement on values to permit a statement of broad principles regarding professional conduct to function both as guidance and ideals for members" (p.8, as cited in Campbell, 2000). Likewise, as cited in the code of ethics provided by University of South California, "ethical behaviour is predicated on two main pillars: a commitment to discharging our obligations to others in a fair and honest manner, and a commitment to respecting the rights and dignity of all persons. As faculty, staff, students, and trustees, we each bear responsibility not only for the ethics of our own behaviour, but also for building our university's stature as an ethical institution" (p.1).

Central to this code as well as any code of ethics, prepared for an academic context, lies a constant concept that encourages the members to "promptly and openly identify and disclose conflicts of interest on the part of faculty, staff, students, trustees, and the institution as a whole, and also to take appropriate steps to either eliminate such conflicts or insure that they do not com-promise the integrity of the individuals involved or that of the university" (as cited in the code of ethics of university of Southern California, p.1).

It is also an engaging point to be born in mind that academic ethics code need to highlight members of the community are demanded to distinguish between ethical behaviour and other types of behaviour such as legal behaviour. On top of this, in terms of avoiding the harassment, mistreating, belittling, harming or taking advantage of any one of the members of the academic society, along with signifying the institute's lack of tolerance for scientific fraud, plagiarism, misrepresentation, cheating or discriminations are among the prominent themes that an ethics code for an academic context is expected to illustrate.

On the other hand, inspiring positive attitudes need to be the stepping stones of any academically relevant code. Such behaviours as mutual respect, dignity and trust, as well as fostering cooperation, encouraging influential critical thinking and taking full responsibility as a community member, ought to be re-enforced among the ethical themes of an academic code of ethics.

More importantly, a code of ethics covers "the ethical identity of the institution including how it understands and articulates its values - as well as how those values are embodied in policy and practice. Hence ethical principles apply to any and all of an institution's operations, from purchasing and estate management to research and teaching" (as stated in the paper on Ethics Matters by the Council for Industry and Higher Education, p.9). Therefore, one might expect an ethical code to go beyond an institution's legal responsibilities mostly try to apply it to the conduct of individuals and the organization as a whole. 


\section{Theoretical Frameworks \& Concepts on the Components of a Code of Professional Ethics}

As the review on components of code of ethics across varied organizations as well as academic contexts depict, the underlying implication of almost all the aforementioned codes are similar and many of the themes recur throughout all their items.

Since the prominent scope of the current research was to provide a model of code of professional ethics based on the instrument and the study which was carried out by Kafi, Motallebzadeh and Ashraf (2017), a close analysis of how they presented a code of professional ethics is established hereby. In their article, they went through a thorough analysis of the available literature and varied samples of codes of ethics presented by various universities inside the country as well as overseas. Some of the codes they underwent for thorough analysis included the following;

- Code of Ethics by Cambridge University Press

- Ethical Code for Research by University of Cambridge-School of Technology

- The Code of Ethics of the University of Southern California

- Code of Conduct by Brown University

- Code of Ethical Conduct by NYU (New York University)

- University Code of Conduct by University of Illinois

- Code of Ethics by University of Iceland

- Radford University Code of Ethics

- Code of Professional Ethics by ISACA

- Code of Ethics for Educators by Association of American Educators

- University of Virginia Code of Ethics

- Australian College of Education Code of Ethics

- Al-Zahra University code of Ethics

- Fani-Herfeii Center of Education

Having studied all the aforementioned codes, Kafi et al. (2017) concluded that these codes were designed and postulated in either of the two following ways;

- The code was designed in an item-wise manner in which one could find a list of notions with no mentioned relevance to the construct they were describing.

- The code included some constructs followed by a paragraph which explained what is meant by that construct.

However, since a code sounds better to be designed in a way that is easy to announce in educational publics, quick to go through, and catchy to remember, they opted a mixture of the above two patterns for designing the code. That is, a code which sets out the prominent educational constructs each of which is explained through some items.

To come up with appropriate constructs/components for the code, available codes of ethics and the available frameworks were both considered in the selection process.

One of the theoretical frameworks that paved the way for these researchers to come up with a sound decision for choosing the most prominent components of an ethics code was the research by Campbell (2000) which singled out six types of relationship that 
teachers are involved in during the course of their work. These six types include the connection of the teachers with "students", "other teachers", "principle and school administrator", "the school", "parents or community" and to "self". Since some of these relations seemed to overlap, this categorization came as an aid to the researchers to put these connections under four major constructs as "learners", "organization", "society" and "profession".

However, from among other available relevant frameworks applicable for academic contexts, the thought pattern postulated by Waldo (1956) seemed the wisest to rely the basis of their research on. The reason this framework was opted rooted in the fact that his model/book is believed to "have done much to broaden the horizons and deepen the intellectual content of academic public administration in the United States as well as many other educational centers" (Chester, 1958, p.238).Therefore, the model was used as a pattern of thought and a kind of mind set for accumulating more data relevant to a code of professional ethics. In Waldo's model, there existed twelve kinds of occupational commitment which cover any aspect of ethics in occupations. However, since the scope of their study centered on ethics in academic contexts (universities), the four components which were directly in line with education were opted as the main constructs. These included Commitment to Society, Commitment to Organization, Commitment to Learners, and Commitment to Profession.

Later on, to make sure of the validity of the selected constructs, a comparison was drawn between these opted constructs and the constructs available in other codes of ethics. Similar components/constructs existed in some of the available codes. For instance, the code of ethics for university of Iceland included principles such as "responsibility with regard to society", "responsibility towards the University of Iceland (organization)", and "mutual responsibility of teachers and students". Another reference was given to the code of ethics for educators postulated by the Association of American Educators which embraced similar notions such as "ethical conduct towards students", "ethical conduct towards parents and community", and "ethical conduct towards performance".

To maintain a clear illustration of what each of these prominent components of an ethics code mean, these researchers provided a comprehensive elaboration on each of the four components, considering both the literature and the immediate academic contexts of this research (as cited in Kafi et al., 2017):

- Commitment to Learners: Following Campbell's (2000) lane of thoughts in her ethics code, in any educational setting, talking about a teacher's commitment to learners/students might refer to "teacher' s demonstration of care, commitment and empathy for students as well as the equitable and respectful treatment of them" (p.6).

- Commitment to Profession: " having more to do with knowledge of curriculum and pedagogy, achievement, the promotion of learning environments, and the inclination to engage with others to effect change"(p.6) are pin pointed by Campbell (2000) as some of the feature a teacher is expected to follow if he/she cares to stand out as a professional .

- Commitment to Organization: As Campbell (2000) illustrates, the school, organization or the district for which a teacher is working, employs or sometimes 
establishes official job expectations for their employees. Consequently, teachers, as members of such institutions are to demonstrate faithfulness, honesty and a sense of responsibility to whatever aspect of their profession which might directly or indirectly harm/benefit the well-being of the organization.

- Commitment to Society: As the Forum on Education Abroad (2008) states in its code of ethics, "by the very nature of education and engaging host societies in myriad ways, teachers need to demonstrate commitment, respect and sensitivity to some societal issues including differences between local cultural norms and those of the home culture, awareness of the program's impact on the local community, commitment to creating sustainable local relationships that are mutually beneficial, and an effort to minimize any negative effects on the society, effective orientation of students, faculty and staff so that they are aware of applicable host and home country ethical and legal practices, and understand the society, in order to avoid actions that negatively impact that society or the image of the home country" (As cited in the Forum of Education Abroad, 2008, p.14).

Therefore, the aforementioned four constructs were opted for the code of professional ethics in their study and later on, relevant items for each of the constructs were extracted out of the available literature.

\section{Research Questions}

1. Which of the four components of the code of professional ethics EFL instructors declare to be the most important?

2. Is there any relationship between Iranian EFL university instructors' teaching experience and their perception of professional ethics?

3. How would a model of code of professional ethics look like based on EFL university instructors' understanding of professional ethics in teaching?

\section{METHOD}

\section{Participants}

The participants in this research included 200 university instructors teaching B.A., M.A. or $\mathrm{PhD}$ programs of English; either translation, teaching or literature. These teacher participants were mostly the ones teaching at Non-Profit universities (40\%), Azad University (33\%) and State universities (13\%). 55 percent of these participants were female and 45 percent included male instructors. Majority of them (72\%) had an age range of 31- 40 and 21 percent of them were aged between 41 and 50 .

Majority, 66 percent, of the attendants were PhD students and 34 percent possessed an M. A degree in either of the three fields of English. As for their teaching experience, 36 percent had an experience of over 15 years and 30 percent were categorized as having 10 to 15 years of experience. Lastly, 65 percent of the instructors possessed an English proficiency level of Excellent and 35 percent declared to have an English proficiency level of very good in the field. The data collection throughout the current study commenced in September 2017 and ended in December 2017. A demographic analysis of the participants is provided in Table 1 . 
Table 1

Demographic Profile of the Participants

\begin{tabular}{llllll}
\hline & & Category & Frequency & Percentage \\
\hline 1 & Gender & Male & 90 & 45.00 \\
& & Female & 110 & 55.00 \\
\hline 2 & \multirow{2}{*}{ Age } & $31-40$ & 144 & 72.00 \\
& & $41-50$ & 42 & 21.00 \\
\hline 3 & Educational Status & M.A & 68 & 34.00 \\
& & PhD Student & 132 & 66.00 \\
\hline 4 & Teaching Experience & $5-10$ & 52 & 26.00 \\
& & $10-15$ & 60 & 30.00 \\
& & Over 15 & 72 & 36.00 \\
\hline 5 & Province & Tehran & 42 & 21.00 \\
& & Khorasan Razavi & 140 & 70.00 \\
& & Others & 18 & 09.00 \\
\hline 6 & \multirow{2}{*}{ University } & Azad & 66 & 33.00 \\
& & Non-Profit & 80 & 40.00 \\
& & State & 26 & 13.00 \\
\hline 7 & \multirow{2}{*}{ English Proficiency } & Very good & 70 & 35.00 \\
& & Excellent & 130 & 65.00 \\
\hline
\end{tabular}

\section{Instrumentation}

\section{Questionnaire on Professional Ethics in Teaching (QPET)}

The QPET questionnaire was a validated and reliable researcher made questionnaire designed by Kafi et al. (2017). Designing this instrument included several stages. As was explained earlier in the study, once the components of the ethics code along with its sub-items/sub-categories were extracted based on the available literature as well as the available codes of ethics, the accumulated content was localized through a structured interview they ran with 50 EFL university instructors. This means that any notion which was highly frequent among teacher participants was added to the current code of professional ethics. At the same time, there existed some notions mentioned by teachers which were already extracted from the literature and this localization process crosschecked the content validity of the code as well. Finally, the modifications to the code were also cross-checked and verified by two experts in the field once the final draft was presented.

Afterwards, the code of professional ethics was used in order to change it into a tool for checking university instructors' understanding of professional ethics in teaching. The questionnaire covered all the four categories of the code of professional ethics, namely as Teachers' Commitment to Learners, Teachers' Commitment to Society, Teachers' Commitment to Profession, and Teachers' Commitment to Organization. Each category embraced 11 to 20 items which compromised a sixty one-item questionnaire through a Five-point Liker Scale.

However, since the researchers did not aim to give the teacher participants a pattern of thought or direct/influence their answers in any way, the titles for all the four categories were eliminated and the questions of all those four categories were fairly distributed throughout the questionnaire so as to accumulate more valid and un-biased answers. 
Considering the validation process of the questionnaire two approaches were taken; expert validation and construct validation. As for the expert validation, once the four categories of the code and the sub-items of each category were extracted out of the related literature, two experts in the field were asked to review the items and give comments on either the notions, the wording of the statements, the relevance of each item to its category, or any other crucial point and the required modifications were applied accordingly. Following this, the researchers went for the localization process of the questionnaire and when the procedure was fully and completely carried out and new items were added to the previous version, once again the revised questionnaire was handed in to the same two experts and they checked the consistency of all the items to their relevant category, the wording of the statements and appropriate modifications were also carried out. Besides, this process could stand as investigating the content validity of the code.

Regarding the statistical construct validation and the reliability of the instrument, they deployed PLS_SEM smart software and various means such as Convergent Validity, Discriminant Validity, Factor Loadings and Cronbach Alpha were used. The results of all the adopted data analysis procedures stood for the questionnaire to be reliable (an index of above 9 for all the four components of the questionnaire) and through the validation process, two of the items were removed from the inventory and the questionnaire ended up in 59 items on a five point Likert scale (Kafi et al., 2017).

\section{Study Design}

As the researchers' primary purpose was to focus on the probable relation between EFL university instructors' understanding of professional ethics and their teaching experience and the study enjoys relevant statistical techniques, the design is expost-factorial. This means, the purpose is to control the product and not the process of the study.

\section{FINDINGS}

Considering the first and the second research questions which centered on quantitative means, the very first measure needed to be taken, was to estimate the normality of the data and based on the obtained results, the appropriate data analysis measures were opted for the study. Kolmogorov-Smirnov was therefore applied through SPSS software and the results are depicted in Table 2.

Table 2

\begin{tabular}{llllll}
\multicolumn{1}{l}{ Kolmogorov-Smirnov Results of Normality } & & \\
\hline & $\begin{array}{l}\text { Teachers' } \\
\text { Commitment } \\
\text { to Learners }\end{array}$ & $\begin{array}{l}\text { Teachers' } \\
\text { Commitment } \\
\text { to Profession }\end{array}$ & $\begin{array}{l}\text { Teachers' } \\
\text { Commitment } \\
\text { to Society }\end{array}$ & $\begin{array}{l}\text { Teachers' } \\
\text { Commitment to } \\
\text { Organization }\end{array}$ & $\begin{array}{l}\text { Professional } \\
\text { Ethics }\end{array}$ \\
\hline Kolmogorov-Smirnov Z & 3.089 & 2.198 & 2.869 & 1.995 & 1.575 \\
Asymp. Sig (2-tailed) & .000 & .000 & .000 & .001 & .014 \\
$\mathrm{~N}$ & 200 & 200 & 200 & 200 & 200 \\
\hline
\end{tabular}

Regarding the results, since all the four variables of the study (commitment to learners, profession, society and organization) possess an Asymp sig of smaller than 0.05 (.000, .001 and .014), the distribution of the variables is not normal and therefore nonparametric means of data analysis were applied. 
To deal with the first research question which centered on prioritizing the four components of the code of professional ethics based on EFL instructors' responses, Friedman Test was applied through SPSS software and the results are presented in Table 3.

Table 3

Friedman Test Rank Order Results

\begin{tabular}{ll}
\hline & Mean Rank \\
\hline Teachers' Commitment to Learners & 2.77 \\
Teachers Commitment to Profession & 2.50 \\
Teachers' Commitment to Organization & 2.40 \\
Teachers' Commitment to Society & 2.34 \\
Asymp. Sig & .001 \\
N & 200 \\
\hline
\end{tabular}

Using Friedman Test, the variables of the study are ranked in the order of importance based on their means. Thus, this could help the researchers locate the fact that which of the four components of professional ethics gained the highest mean based on the responses gathered from EFL instructors. According to Table 3, from among the four components of the code of professional ethics, Commitment to Learners, Commitment to Profession, Commitment to Society and Commitment to Organization, stand from the most to the least important constructs of professional ethics based on the responses provided by EFL instructors. Besides, Table 3 stresses the significance of the difference between the means for each of the four variables $(0.001<0.05)$. Therefore, EFL instructors' lack of awareness about the other two aspects of code of professional ethics (Commitment to Society and Commitment to Organization) is highlighted.

This finding is close to the research carried out by Salehnia and Ashraf (2015) who found out that 'respect to the institution's principles', as one of the principles of professional ethics, possessed the least amount of correspondence with students' level of self-esteem. Therefore, they also highlighted the fact that promoting ethics in the organization not only creates a favorable environment for increased productivity, but also has a more effective role in society.

Dealing with the second research question which aimed at investigating the probable relation between EFL instructors' teaching experience and their understanding of professional ethics, Pearson Correlation was employed and the results are depicted in Table 4.

Table 4

Pearson Correlation Results

\begin{tabular}{|c|c|c|c|}
\hline & & $\begin{array}{l}\text { Years of Teaching } \\
\text { Experience }\end{array}$ & $\begin{array}{l}\text { Professional } \\
\text { Ethics }\end{array}$ \\
\hline Years of & Pearson Correlation & 1 & .015 \\
\hline \multirow[t]{2}{*}{ Teaching Experience } & Sig. (2-tailed) & & .836 \\
\hline & $\mathrm{N}$ & 200 & 200 \\
\hline \multirow[t]{2}{*}{ Professional Ethics } & Pearson Correlation & .015 & 1 \\
\hline & Sig. (2-tailed) & $\begin{array}{l}.836 \\
200\end{array}$ & 200 \\
\hline
\end{tabular}


As depicted in Table 4, the sig. (0.8) is larger than the level of significance (0.05); therefore, there did not exist a statistically significant relation between instructors' teaching experience and their professional ethics. This means, though teaching experience can affect a person's sense of professional ethics, there is no guarantee to claim that whoever possesses a high level of working experience will necessarily possess a good understanding of professional ethics.

This outcome proved the opposite as compared to another study which was carried out on 200 female teachers in India (Kumar \& Kaur, 2014). In their case, the Pearson correlation proved there existed a statistically significant relation between teachers' teaching experience and their professional ethics which means in case of those female Indian teachers, 'professional ethics grow with experience.' This might be rooted in some individual, societal or even cultural differences.

The concluding point goes to the third research question which centers on postulating a model of code of professional ethics based on EFL university instructors' understanding of ethics in teaching. All the data analysis procedures and findings previously adopted throughout qualitative means by Kafi et al. (2017) and the quantitative means established in the current study proved similar outcomes. Analyzing EFL instructors' ideas about components of a code of professional ethics for an EFL context by Kafi et al. (2017) and investigating the rank order to establish the importance of the four components of code of professional ethics based on quantitative data in this study, all stood out for the importance these instructors attached to the kind of responsibility and commitment they have towards their learners and their profession respectively. However, when it came to their understanding of the kind of commitment they needed to have towards their society and towards the organization they were working for, almost no significant responses were accumulated. This fact calls for some instructional, as well as awareness-raising programs regarding the other two aspects of professional ethics in teaching. Therefore, enriching the current study based on the accumulated data, the following model of code of professional ethics for EFL university instructors is postulated in Figure 1.

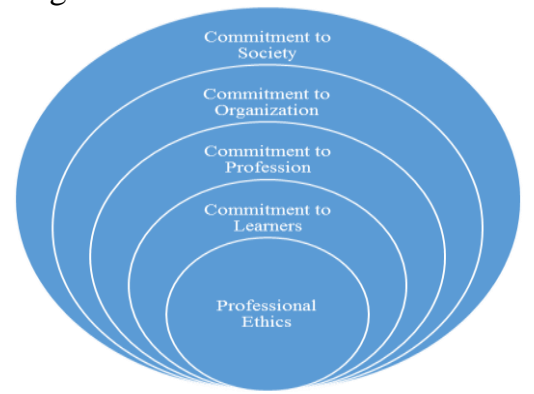

Figure 1

Model of Code of Professional Ethics for EFL University Instructors

As illustrated through Figure 1, Iranian university instructors' understanding of professional ethics in teaching, embraces at its heart the kind of responsibility and commitment they feel they have towards their learners, to whom they devote most of 
their worries, energy, time, efforts etc., and on the other hand, stands the society as the least important concept they find themselves attached to! Seems the fact that learners of our classrooms, who are the members of the society to which they will soon return, is dramatically missing in the process of pursuing professional ethics in teaching! The postulated model can also find its roots in line with the outcomes of previous correlational studies in EFL contexts, namely as the ones carried out by Salehnia \& Ashraf (2015) as well as Ashraf, Hosseinnia \& Domsky (2017), who all stressed the issue that respect and commitment to institution (organization) is the component which is missing in EFL teachers' understanding of professional ethics in teaching.

\section{DISCUSSION AND CONCLUSION}

Reflecting on all the already discussed, it seems even more crucial than ever before, to consider ethical foundations in all and any educational context specifically universities which are considered as the birth place of novel thoughts as well as societal relations. This is even more of a necessity in EFL contexts which have very recently been in touch with the notion of ethics. The need for this action to be taken has also been highlighted by researchers including Strike \& Ternasky (1993) who claim, "education to date it seems, has neither deliberate and systematic instruction in ethics nor an enforceable code of ethics" (p. 3) (as cited in Campbell,2000, p.19). Codes of ethics can be assumed as one of the best practical ways of providing teachers with the right intuition about how to approach various ethical concepts which might be relevant to students, colleagues, the organization or even the society. All this is needed cause as Campbell (1997) stresses, "professionals' sense of moral agency does not inevitably emerge as a result of their training and education, but instead needs to be developed in a deliberate way through the teaching of ethics to teachers" (as cited in Freeman, 2000, p.6) and the presence of a professional ethics code can be one such deliberate ways of raising teachers' awareness of ethical codes in education.

Regarding the very immediate outcomes of this study, it was revealed that university instructors possess a very limited world view and perception about professional ethics in teaching when it comes to the two components of 'commitment to organization and commitment to society'. This is because they probably have not taken the notion of professional ethics as a social-educational concept and this fallacy might be rooted in the fact that professional ethics and its products are not considered as a "value" in some educational communities. Therefore, the outcomes of this study highlight the fact that there needs to be some future measures taken by educational authorities to raise university instructors' awareness regarding those aspects of professional ethics that seem to be untouched by EFL instructors (commitment to organization \& commitment to society). The postulated model of code of professional ethics and the presented instrument can both be applied as tools to enhance the awareness-raising process of the university instructors.

Another important point regarding the data analysis of the current study, is the notion of ethics not being experience-sensitive! This means ethics can be considered an individual factor before its being an important issue in teaching. Therefore, a teacher, experienced or not, may or may not follow ethical standards at his/her workplace which means being 
experienced can be 'one' of the many factors that might affect a person being an ethical teacher. However, it is not a defining factor. Consequently, based on the outcomes of the study, it seems that there is no guarantee to claim that a highly experienced teacher is necessarily a professionally ethical one and also the other way around! This outcome proved the opposite as compared to another research which was carried out on 200 female teachers in India (Kumar \& Kaur, 2014). In their case, the Pearson correlation proved there existed a statistically significant relation between teachers' teaching experience and their professional ethics which means in case of those female Indian teachers, 'professional ethics grow with experience.' This might be rooted in some individual, societal or even cultural differences.

\section{Future Research Directions}

To add to the knowledge repertoire of the practitioners, it could be quite worthy to investigate whether teachers working in private sectors, including language schools, also maintain the same world view regarding professional ethics in teaching. Besides all the above mentioned, there exists the need for holding varied sessions in which professional ethics, its concept at the level of universities and higher education, and its potential positive effects on EFL educational system be explicitly taught and teachers be well trained in the realm of ethics in education!

All in all, Also, as Hutchings (2016) stresses, "professionals are prepared to not only think about critical decision points, but also to discuss them with each other by applying a common framework of understanding and for that very reason, codes of ethics have been at the core of most professions for decades" (p.3). Accordingly, providing such ethical codes as well as direct and indirect instructions to EFL instructors about the notion of professional ethics, needs to be considered a priority for all educational organizations in the $21^{\text {st }}$ century!

\section{REFERENCES}

Ashraf, H., Hosseinnia, M., and Domsky, J. (2017). EFL teachers' commitment to professional ethics and their emotional intelligence: A relationship study. Educational Psychology and Counselling, 2(4), 1-9.

Australian College of Education. (1987). Code of ethics. As cited in Haynes, F. (1998). The Ethical School, London; Rutledge.

Beck, L., \& Murphy, J. (1994). Ethics in educational leadership programs: An expanding role. Thousand Oaks, CA: Corwin.

Campbell, E. (1997). Connecting the ethics of teaching and moral education. Journal of Teacher Education, 48(4), 255-263.

Campbell, E., (2008). The Ethics of Teaching as a Moral Profession. Ontario Institute for Studies in Education, University of Toronto, Toronto, ON, Canada.

Campbell, E. (2000). Professional Ethics in Teaching: Towards the development of a code of practice. Cambridge Journal of Education, 30:2, 203-221.

Code of Ethics for Education Abroad, (2008). A Copyright from the Forum on Education Abroad. 
Freeman, N. K. (2000). Professional Ethics: A Cornerstone of Teachers' Pre-service Curriculum. Action in Teacher Education, 22:3, 12-18.

Hansen, D. T. (2001). Teaching as a moral activity. In V. Richardson (Ed.), Handbook of research on teaching (4th ed.; pp. 826-857). Washington, DC: American Educational Research Association.

Haynes, F. (1998). The ethical school. London: Routledge.

Hostetler, K. D. (1997). Ethical judgment in teaching. Boston: Allyn \& Bacon.

Hutchings, T., (2016). Protecting the Profession-professional ethics in the classroom. Educational Testing Service; ETS.

Kafi, Z., Motallebzadeh, Kh., \& Ashraf, H. (2017). Developing, Localizing and Validating Code of Professional Ethics: University Instructors' Perspective. A paper submitted for publication.

Kipnis, K. (1986). Legal ethics. Prentice-Hall Series in Occupational Ethics. Englewood Cliffs, NJ: Prentice Hall.

Kumar, S., \& Kaur, S. (2014). Professional Ethics Grow with Teaching Experience: A Study of Women Teachers in Higher Education Institutions of Punjab. European Academic Research, 2 (4), 5904-5922.

Lovat, T. J. (1998). Ethics and ethics education: Professional and curricular best practice. Curriculum Perspectives, 18(1), 1-7.

Nash, R. J. (1996). Real world ethics: Frameworks for educators and human service professionals. New York: Teachers College Press.

Salehnia, N., and Ashraf, H. (2015). On the Relationship between Iranian EFL Teachers' Commitment to Professional Ethics and their Students' Self-Esteem. Mediterranean Journal of Social Sciences, 6 (5), 135-143.

Santoro, N., Reid, J., Mayer, D., \& Singh, M. (2012). Producing 'quality' teachers: the role of teacher professional standards. Asia-Pacific Journal of Teacher Education, 40:1, $1-3$.

Sockett, H. (1992). The moral aspects of the curriculum. In P. W. Jackson (Ed.), Handbook of research on curriculum (pp. 543-569). New York: Macmillan.

Strike, K.A. \& Ternasky, P.L. (1993). Ethics for Professionals in Education: perspectives for preparation and practice. New York; Teachers College Press.

Tanchuk, N., \& Scramstad, C., \& Kruse, M., (2016). Toward an ethics of professional understanding. Ethics and Education, 11:1, 5-16.

Waldo, D. (1956). Perspectives on Administration. University, AL: University of Alabama Press.

Azhar M. (2007) Level Of Professionalisme Among Islamic Education Trainees In Practical Teaching, unpublished Masters thesis, Universiti Teknologi Malaysia, retrieved September 2011 from eprints.utm.my/4276/1/75215.pdf. 